\title{
Teacher Management Online Learning to Improve Student Learning Outcomes of State Elementary Schools at District of Beringin Island
}

\author{
Sri Suparti ${ }^{1 *}$, Yasir Arafat ${ }^{2}$, Alhadi Yan Putra ${ }^{2}$ \\ ${ }^{I}$ SDN 12 Pulau Beringin, OKU Selatan \\ ${ }^{2}$ Universitas PGRI Palembang \\ *Corresponding author. E-mail: srisupartinasa@gmail.com
}

\begin{abstract}
Covid-19 has drastically changed the learning model from conventional learning to online learning. This article aimed to determine how teacher management in online learning improves student learning outcomes, and to give solutions in online learning problem. The method used descriptive qualitative with data collection techniques through interviews, observation and documentation. The result showed that learning using an online model at the 12 Beringin Island Elementary School, South OKU district has been effective by utilizing the application Google Classroom, Google meet. Indeed, there are still several obstacles in its implementation, namely the problem of internet connection which was often interrupted. And the unavailability of internet quota for students. The solution that can be taken was to allocate school operational assistance funds to finance students' internet quota. Researchers suggest that teachers must prepare learning implementation plans, methods, media and online learning applications to improve student learning outcomes.
\end{abstract}

Keywords: Learning Online, Management Learning Online, Teacher Learning Online

\section{INTRODUCTION}

Information technology continues to evolve along with the development of human civilization. The management and delivery of information continues to evolve, starting from the form of images, printing machines, computers, telegraphs, telephones, radio, television, to the existing internet. The development of information technology has accelerated since the advent of the internet. The internet successfully combines computer and telecommunication technology. [1][2] The internet network has become the pioneer of the technological revolution. The emergence of the internet gave birth to a new world that had different characteristics from the real world and succeeded in influencing various aspects of human life [3]. The Internet can change the behavior of technology users and the patterns of everyday life, and can change existing systems, for example in the fields of business, government, education, journalism. The use of information technology in education is one way that can be used to increase the effectiveness and quality of education. [4][5] Information technology can also be used as a product that can be used in education and as content or part of material that can be used as content in education.
Furthermore, the students can also communicate directly with their sources without going through a complicated bureaucracy and are not limited by space and time [6]. Students are more flexible in following the educational process, but interactions with educators continue well. At this time, the world is facing an outbreak of the Covid-19 virus, which is spread almost evenly throughout the country. Our country has not been spared from this epidemic which has an impact on various sectors, including the education sector.[7][8] Other studies asserted that Facilities and infrastructure Existing education is able to support learning during the Covid-19 pandemic with good and optimal. Education will not possibly be carried out properly and optimal without being supported by the supporting facilities and infrastructure the learning process was carried out well, especially during the Covid -19 pandemic. [9]

While, Some state policies decide to isolate policies in an attempt to slowing the spread of the plague. In response to this outbreak, it is the most affected countries chose to set their national policies to slow this pandemic by shutting it down public activities and school. [10] [11]. In Indonesia Nadiem Anwar Makarim took a policy of stopping face-to-face schooling 
activities which were replaced by distance learning. (Ministry of Education and Culture)

By paying attention to the conditions that occur in the background above, this is what underlies the researchers to find more clear and factual information in SDN - SDN, Pulau Beringin subdistrict.

To clarify the scope of the problem to be discussed and so that the research is carried out in a focused manner, the limitation of the problem in the research carried out is related to teacher management in online learning in improving the learning outcomes of public elementary school students in the Banyan Island district.The objectives of this study are: (1) To determine teacher management in planning online learning curriculum in improving the learning outcomes of public elementary school students in the Banyan Island sub-district, (2) to find out the solutions to these online learning barriers.

\section{Definition of Management}

Management is defined as knowledge, tips, and a profession. As quoted by Nanang Fattah from Luther Gulick: Stating that management is seen as a knowledge area that systematically seeks to understand why and how people work together. Said to be a trick by Follet because management achieves goals through means of managing others to carry out their duties. It is seen as a profession because management is based on special skills to achieve a manager's achievement, and professionals are guided by a code of ethics. [12] Management can be defined as the art and science of planning, organizing, arranging, directing, and controlling resources to achieve predetermined goals. [13]

\section{Management Functions}

Ricky W. Griffin defines management as a process of planning, organizing, coordinating, and controlling resources to achieve goals effectively and efficiently. Effective means that goals can be achieved according to planning, while efficient means that existing tasks are carried out correctly, organized, and on schedule. [14]

\section{Definition of Teacher}

According to Nafrin, I., Kaunang, N., \& Santie teachers are educators, adults who are responsible for providing guidance or assistance to students in the development of body and soul to reach maturity, able to stand alone to carry out their duties as khalifah of Allah on earth, as social beings and individuals who are able to stand alone. [15] According to Dri Atmaka, educators are people who are responsible for providing assistance to students in both physical and spiritual development. [16] So, being a good and professional teacher is not only able to communicate with the classroom and school environment, but also has good relations with the surrounding community. can be a source of knowledge for society and make a positive contribution.

\section{Definitions of learning administration.}

Administration Simply put, administration comes from the Latin words "ad" and "ministro". Ad means "to" and ministro means "to serve". Freely it can be interpreted that the administration is a service or dedication to a certain subject [17]

The word learning is a translation of instruction which is widely used in the world of education. Whereas teaching is part of learning (instruction), where the role of the teacher is more emphasized on how to design or arrange various sources and facilities available for later use by students or students in learning something. [18]

So learning administration is an activity carried out by teachers or educators in the teaching and learning process, including plans for implementing learning, lists of assessments etc.

\section{Activities in the Learning Process}

This activity is closely related to the duties of a teacher. The task of a teacher as an educator must be managed administratively to ensure the smooth implementation of learning in class. As for these tasks, among others: (1) Compiling a program implementation plan, (2) Arranging a schedule for implementing learning activities, (3) Filling in the learning progress assessment list.

\section{Online Learning}

blogs as online media can be used for the learning process through a process-based approach. So that students can improve their skills including content, organization, discourse markers, vocabulary, sentence construction and writing mechanisms. Schools think in such a way as to attract students to use technology. [19]

\subsubsection{Online Learning Concepts}

The current pandemic condition requires educators, in this case, teachers to innovate in changing face-toface learning patterns into face-to-face learning patterns. . [20] explained that there are other learning models that can be used by teaching staff as a medium for delivering knowledge, namely online learning and mixed learning (a combination of two learning methods, namely faceto-face and online learning).

Online learning or e-learning is a form of learning model that is facilitated and supported by the use of information and communication technology. Elearning can be defined as a form of information technology applied in education in the form of cyberspace[21] 2.6.2. Study From Home

The Health Quarantine Law Article 59 Paragraph 3 of 2020 explains that "these large-scale social restrictions include at least school and work vacations, restrictions on religious activities, and / or restrictions on activities in public places or facilities." This results in the learning time being unable to be carried out at school. Therefore, learning must be done in each house (study from home). [22] 


\section{Learning Outcomes}

According to Hilgard, learning outcomes are abilities obtained by individuals after the learning process takes place, which can provide changes in behavior, both knowledge, understanding, attitudes and skills of students so that they become better than before. [23]. According to Suprijono, learning outcomes can be interpreted as the maximum results a student has achieved after experiencing the teaching and learning process in learning certain subject matter [24] . Learning outcomes are not absolutely in the form of values, but can be in the form of changes, reasoning, discipline, skills and so on that lead to positive change.

According to Khusniyah, NL, \& Hakim, L. in his research, he put forward the conclusion, namely The results of the data analysis show that blogs have a positive effect on the learning process to read English. So that it also has an impact on increasing the grades obtained by students [25] While According to Suci, MP in the effectiveness of online-based learning in insya 'courses at STAI Ma'arif Sarolangun in its conclusion, it explains that for the preparation of an online learning system, universities must make a lot of preparations, such as improvements and revitalization, both in terms of infrastructure and infrastructure and resources. [26] Indeed, to face the digital era, adjustments must be made as quickly as possible because technology is developing so fast that it is unable to be contained.

Researchers concluded that that if online learning is carried out optimally, it will get satisfactory results for both teachers, parents and students although achieving good results is not easy, because there are inhibiting factors behind it. Among other things, online facilities and infrastructure as well as the human resources of the teaching staff

\section{METHODS}

This research was conducted at SDN Pulau Beringin, Pulau Beringin Subdistrict, Oku Selatan Regency, which was held from October 2020 to January 2021.

\subsection{Research Methods}

In this study is a qualitative descriptive study with a case study approach, with a qualitative descriptive approach, analysis of the data obtained (in the form of words, pictures or behavior), and not written in the form of numbers or statistical figures, but by providing Exposure or depiction of the situation or condition under study in the form of a narrative description. The explanation must be done objectively so that the researcher's subjectivity in making interpretations can be avoided. [27]

\subsection{Data and Data Sources}

The data sources in this study are the subjects from which data can be obtained, whether questionnaires or interviews

\subsubsection{Primary data}

Primary data sources, namely data collected directly by researchers from the first source or data taken without intermediaries, from the source, or humans who are directly related to the research, primary data is obtained by distributing questionnaires, conducting interviews or conducting direct observations on something related to research.

Table 1. Primary data sources

\begin{tabular}{|l|l|l|l|l|l|}
\hline \multirow{2}{*}{ No. } & \multicolumn{1}{|c|}{ Identification } & \multirow{2}{*}{ Data source } & \multicolumn{3}{|c|}{ Data collection instruments } \\
\cline { 4 - 6 } & & & Interview & Observation & Documentation \\
\hline 1. & Curriculum & Headmaster & $\checkmark$ & & \\
\hline 2. & Learning methods & Headmaster, & $\checkmark$ & & \\
\hline 3. & Connection facilities & Headmaster & $\checkmark$ & & \\
\hline 4. & Vision \& Mission & Operator & & $\checkmark$ & \\
\hline 5. & Barriers \& Solutions & Headmaster & $\checkmark$ & & \\
\hline 6. & Adm. Learning & teacher & & & \\
\hline 7. & Learning methods & teacher & $\checkmark$ & & \\
\hline 8. & Application used & teacher & $\checkmark$ & & \\
\hline 9. & Process $/$ media & teacher & $\checkmark$ & & \\
\hline 10. & Learning outcomes & teacher & & $\checkmark$ & \\
\hline 11. & General decription & Operator & & & $\checkmark$ \\
\hline 12. & Educator's state & Operator & & & $\checkmark$ \\
\hline 13. & The number of students. & Operator & & & \\
\hline 14. & Barriers to PJJ & Students & $\checkmark$ & & \\
\hline 15. & Benenfits of PJJ & Students & $\checkmark$ & & \\
\hline 16. & How to teach teachers & Students & $\checkmark$ & $\checkmark$ & \\
\hline
\end{tabular}

\subsubsection{Secondary data}

Sources of secondary data obtained by researchers are data obtained directly from related parties in the form of school data and various literature relevant to the discussion, such as documents at SDN 12 Pulau Beringin.

Table 2. Informants

\begin{tabular}{|l|l|c|l|l|}
\hline No. & Informant's name & age & \multicolumn{1}{|c|}{ as } & Profession \\
\hline 1. & Wenti, S.Pd. & 45 th. & Key informants & Headmaster \\
\hline 2. & Salman, S.Pd.I & 43 th. & Main informant & Teacher \\
\hline 3. & Budianto & 12 th. & Supporting informants 1 & Students \\
\hline 4. & Sumarni & 12 th. & Supporting informants 2 & Student 1 \\
\hline 5. & Maria Ulfa & 12 th. & Supporting informants 3 & Student 2 \\
\hline 6. & Leza & 12 th. & Supporting informants 4 & Student 3 \\
\hline 7. & Linda Qktayiani & 12 th. & Supportinginformants 5 & Student 4 \\
\hline
\end{tabular}

Table 3. interview topics

\begin{tabular}{|r|l|}
\hline A. & Key informant interviews \\
\hline 1. & What kind of curriculum is implemented in this school? \\
2. & What learning methods are used by the teachers here...? \\
3. & How is the state of the internet connection facility in this school? \\
4. & What are the views about obstacles and solutions in implementing online learning so far? \\
\hline B. & Interview with key informants \\
\hline 1. & What learning methods do you use? \\
2. & What forms of application do teachers and students use? \\
3. & What is the learning process in the midst of the Covid-19 pandemic \\
\hline C. & Interriew with Supporting informants \\
\hline 1. & What are the obstacles or obstacles in online learning? \\
2. & Is this online learning useful for you ..? \\
3. & What kind of learning, you like? \\
\hline
\end{tabular}

\subsection{Interview}

According to the key informant (Mrs. Wenti), that the curriculum used is $\mathrm{K}-13$, the success or failure of the implementation of learning, is influenced by the method, media, learning program plans by the teacher, indeed in online learning there are still many obstacles or relationships such as (1) internet connection, (2) ownership of devices, both teachers and students, (3) personal abilities in using devices. (4) the ability to use applications for online learning. Solutions in overcoming obstacles include: (1) Teachers must prepare administration / learning tools, (2) teachers can help students who do not have smartphone equipment, namely by asking parents of students to attend school 
for use take the material / module on the days that have been scheduled,

According to the main informant (Mr. Salman), the learning method used by SDN 12 Oulau Banyan teachers is blended learning, this method uses online as well as face-to-face through video converence, the application used is googleclassroom, but some use zoom or googlemeet. Regarding the learning process, I asked a few short questions, which I shared through Google Classroom, then I waited for the student's answers for the next week, to be collected in school. Next, I will correct, and I will share the scores on Google Classroom.

\section{RESULTS AND DISCUSSION}

\subsection{Research Result}

The results of the research, which the researchers conducted from November to December 2020

\subsubsection{General description}

Table 4. General description

\begin{tabular}{|l|l|l|l|}
\hline 1 & School name & $:$ & SDN 12 BERINGIN ISLAND \\
\hline 2 & Accreditation & $:$ & B \\
\hline 3 & School status & $:$ & State \\
\hline 4 & NPSN & $:$ & 10610159 \\
\hline 5 & School Establishment Decree & $:$ & $800 / 123 /$ kpts / 89 \\
\hline 6 & ISO certification & $:$ & $9001: 2000$ \\
\hline 7 & Curriculum & $:$ & Curriculum 2013 \\
\hline 8 & Study time & $:$ & Combination \\
\hline 9 & Power Source & $:$ & PLN \\
\hline 10 & Building & $:$ & Permanent Concrete. \\
\hline 11 & Address & $:$ & Jalan Raya Kemu, beringin. \\
\hline 12 & disland district \\
\hline 13 & Province & $:$ & South OKU \\
\hline 14 & Headmaster & $:$ & South Sumatra \\
\hline 15 & Geographical location & $:$ & Dalianah, S.P. \\
\hline 16 & Internet access & $:$ & -4.493386062001382, \\
\hline
\end{tabular}

\subsubsection{History of Leadership}

Table 5. History of leadership

\begin{tabular}{|c|c|l|}
\hline No. & Period & \multicolumn{1}{|c|}{ Headquater } \\
\hline 1 & $1979-1994$ & Rohama \\
\hline 2 & $1994-2001$ & Lahmudin \\
\hline 3 & $2001-2006$ & Bunaimah, A.Ma.Pd. \\
\hline 4 & $2006-2011$ & Suarni, A.Ma.Pd. \\
\hline 5 & $2011-2012$ & Rusmawati, A.Ma.Pd. \\
\hline 6 & $2012-2014$ & Susriwati, A.Ma.Pd. \\
\hline 7 & $2014-2017$ & Asnalispati, S.Pd.SD \\
\hline 8 & $2017-2019$ & Mesrawarna, A.Ma.Pd. \\
\hline 9 & 2019 until now & D Expertise, S.Pd. \\
\hline
\end{tabular}

Table 6. Educators and education personnel

\begin{tabular}{|c|c|c|c|}
\hline No. & Teacher name & Position & Duty \\
\hline 1. & Dalianah, S.Pd.SD & Headmaster & $\begin{array}{l}\text { Class IA, IB, II, III A, } \\
\text { III B, VI A, VI B }\end{array}$ \\
\hline 2. & Suhaili, S.Pd.I & Subject teacher & III $\mathrm{A}$ \\
\hline 3. & Nuyaharni, S.Pd. & Classroom teacher & II $\mathrm{A}$, II $\mathrm{B}$ \\
\hline 4. & Tahyuda, AMaPd. & Classroom teacher & VA \\
\hline 5. & Mislahartini, S.Pd. & Classroom teacher & VIA \\
\hline 6. & Hisnaini, S.Pd. & Classroom teacher & $1 \mathrm{~A}$ \\
\hline 7. & Sri Suparti, S.Pd.SD & Classroom teacher & 1B \\
\hline 8. & Hisnah Amidawati, S.Pd.SD & Classroom teacher & $\begin{array}{l}\text { III A, III B, IV A, } \\
\text { IV B, VA, VI A, VI B }\end{array}$ \\
\hline 9. & Aslansxah, S.Pd. & Subjec teacher & IV A, IV B, VB \\
\hline 10. & Urfixah, S.Pd.I & Maple teacher & VIB \\
\hline 11. & Yuni Sustina A.MaPd & Classroom teacher & IV B \\
\hline 12. & Nasidariah, S.P..SD & Classroom teacher & III B \\
\hline 13. & M. Toib Mutawib, S.Pd.SD & Classroom teacher & III B \\
\hline 14. & DwiHartuti, S.Pd.SD & Subjec teacher & IV A \\
\hline 15. & Meri Apriani, S.Pd. & Classroom teacher & VB \\
\hline
\end{tabular}

Table 7. Description of students

\begin{tabular}{|c|c|c|c|c|}
\hline No. & Class & Male & Women & total \\
\hline 1. & I. $\quad A \backslash B$ & 21 & 24 & 45 \\
\hline 2. & II. $\mathrm{A} \backslash \mathrm{B}$ & 15 & 27 & 42 \\
\hline 3. & III. $A \backslash B$ & 18 & 26 & 44 \\
\hline 4. & IV. $\mathrm{A} \backslash \mathrm{B}$ & 15 & 35 & 48 \\
\hline 5. & V. $A \backslash B$ & 23 & 29 & 52 \\
\hline 6. & VI. $\quad A \backslash B$ & 14 & 36 & 50 \\
\hline & tot & 106 & 177 & 281 \\
\hline
\end{tabular}

\subsection{Discussion}

4.2.1. The teacher's efforts in preparing learning materials

Based on the results of the research findings above, in the teaching process of teachers in processing and preparing Mathematics learning materials for class VA are in accordance with: (1) syllabus and lesson plans, (2) teachers master the material well, (3) teachers are full of confidence, (4) the teacher delivers the material systematically. This research is in line with [18] Mastering subject matter is the main requirement to be an ideal teacher. [28]

4.2.2. The teacher's efforts in choosing learning methods

The method is a method used to implement learning plans so that learning objectives are achieved optimally. When the researcher made observations, the teacher had: (1) used a method that was in accordance with the material, (2) used the online lecture method, (3) showed an animated video about the learning material. This research is in line with [29], the use of a teaching method besides being motivated by several factors.

4.2.3. Teachers' efforts in Using Learning Media

Teachers must have basic skills in choosing natural media to improve student learning outcomes.

When researchers conducted observations of online learning media used by SDN 12 Pulau Beringin teachers, using animation videos and video tutorials in the zoom and google meet application. This is in line with Each teaching medium has certain characteristics, both in terms of effectiveness, manufacture, and how to use it.

4.2.4. Efforts of teachers in application selection

In information and communication technology (ICT), applications are programs used to implement 
learning plans. This research is in line with [3], There are several learning applications that are widely used lately. Namely: (1) Whatsapp Group, (2) Google Classroom, (3) Zoom, (4) Google Meet. [29]

4.2.5. Teachers' Efforts to Overcome Barriers.

the obstacles or obstacles: (1) the condition of the parents of students who use the WhatsApps application more, (2) the second is the difficulty of finding the internet network, (3) smart phone devices that are more often carried by working parents.

\section{CONCLUSION AND SUGGESTION 5.1. Conclusion}

The impact of COVID-19 on the online learning process in primary schools is felt by students, parents and teachers. With the online learning method, teachers, parents and students need time to adapt, in an effort to increase all the potential of students. Therefore, teachers must be ready to face these changes, for example, teachers must prepare online-based methods, syllabus and lesson plans, online learning media and applications for online learning. solutions for elementary school students in grades I to III who have not been able to operate technological devices, teachers and parents must work together, such as: (1) the teacher will provide learning modules to students via e-mail of the students' parents, (2) the teacher asks parents the student comes to take the module to school.

\subsection{Suggestion}

Researchers' suggestions for: (1) school principals, so that they can provide internet quota assistance, for example obtaining it from BOS funding sources, (2) Teachers, do not give too many school assignments to students.

\section{REFERENCES}

[1]. Cahyono, H., Iswati, I., Yusuf, M., Umar Al Faruq, A. H., \& Sidik, M. A. (2021). Pelatihan Shooting Movie Islami Sebagai Media Pembelajaran Siswa SMP Islam Darul Muttaqin. Bulletin of Community Engagement, 1(1), 38-42.

[2]. Suhono, S., \& Sari, D. A. (2020). Developing Students' Worksheet Based Educational Comic for Eleventh Grade of Vocational High School Agriculture. Anglophile Journal, 1(1), 29-40.

[3]. Suhono, S., Zuniati, M., Pratiwi, W., \& Hasyim, U. A. A. (2020). Clarifying Google Translate Problems Of Indonesia-English Translation Of Abstract Scientific Writing.

[4]. Wawan, W., Marsigit, M., Ningsih, E. F., Widyawati, S., Kusumaningtyas, W., Mahmudi, M., \& Setiawan, A. (2018). Technology-Integrated Collaborative Learning: Convenient Al-ternative in Developing the Problem Solving Capability and Positive Attitude. International Journal of Engineering \& Technology, 7(3.2), 737-740.

[5]. Furneaux, C. (2004). Social innovation and social enterprise: Evidence from Australia Challenge social innovation (pp. 215-237): Springer.
[6]. Baharun, H. (2016). Performance management in increasing competitive advantage in Islamic educational institutions. At-Tajdid: Journal of Tarbiyah Science, 5 (2), 243-262.

[7]. Ilyasa, F., Rahmayanti, H., Muzani, M., Ichsan, I. Z., \& Suhono, S. (2020). Environmental education for prevent disaster: a survey of students knowledge in beginning new normal of COVID19. International Journal on Advanced Science, Education, and Religion, 3(2), 1-8.

[8]. Muslimin, E., Fajrussalam, H., Syah, M., \& Erihadiana, M. (2021). The Implementation of Educational Facilities and Infrastructure Management in Supporting Learning Process during Pandemic Covid-19 (Study at SMA Plus As-Salaam Bandung). Bulletin of Science Education, 1(2), 116-123.

[9]. Rahimah, R., Juriah, N., Karimah, N., Hilmatunnisa, H., \& Sandra, T. (2020). The Problems and Solutions for Learning Activities during Covid-19 Pandemic Disruption in Hidayatul Insan Pondok School. Bulletin of Community Engagement, 1(1), 13-20.

[10]. Manullang, S. O., \& Satria, E. (2020). The review of the international voices on the responses of the worldwide school closures policy searching during Covid-19 pandemic. Jurnal Iqra': Kajian Ilmu Pendidikan, 5(2), 1-13.

[11]. Putra, P., Liriwati, F. Y., Tahrim, T., Syafrudin, S., \& Aslan, A. (2020). The students learning from home experiences during Covid-19 school closures policy in Indonesia. Jurnal Iqra': Kajian Ilmu Pendidikan, 5(2), 30-42.

[12]. Manullang, M. (2012). Management basics: Deli.

[13]. Gaylord, B., Kroeker, KJ, Sunday, JM, Anderson, KM, Barry, JP, Brown, NE ,. . . Hall-Spencer, JM (2015). Ocean acidification through the lens of ecological theory. Ecology, 96

[14]. Batlajery, S. (2016). Implementation of Management Functions in the Government Apparatus of Kampung Tambat, Merauke Regency. Journal of Economic \& Social Sciences, 7 (2), 135-155.

[15]. Nafrin, I., Kaunang, N., \& Santie, Y. (2018). The role of civic education teachers in improving discipline for students of SMA Negeri 1 Kulisusu, Buton Utara district, Southeast Sulawesi province. Journal of Civic Education: Media of Pancasila and Citizenship Studies, 2 (2), 62-68

[16]. Halimah, S. (2019). Teachers' Efforts in Forming Children's Morals in Raudlotul Athfal Baipas Roudlotul Jannah Malang City. Dewantara's Journal, 1 (1), 1-6.

[17]. Purwanto, MN (2019). Educational administration and supervision.

[18]. Sidek, EAR, \& Yunus, MM (2012). Students' experiences on using blog as learning journals. Bahri, DS (2014). Teachers and Students in Educational Interaction. Jakarta: Rineka Cipta.

[19]. Procedia-social and behavioral sciences, 67, 
[20]. Hanum, NS (2013). The effectiveness of e-learning as a learning medium (evaluation study of the elearning learning model of SMK Telkom Sandhy Putra Purwokerto). Journal of Vocational Education, 3(1)

[21]. Handarini, OI, \& Wulandari, SS (2020). Online Learning as a Study From Home (SFH) Effort During the Covid Pandemic 19. Jurnal Pendidikan AdMinistrasi Office (JPAP),

[22]. Sjukur, SB (2012). The effect of blended learning on learning motivation and student learning outcomes at the SMK level. Journal of vocational education, 2 (3).

[23]. Setiaji, R., Koeswanti, HD, \& Giarti, S. (2018). The Difference in the Use of Discovery Learning and Problem Solving to the Science Learning Outcomes of Grade 4 Students of SD Gugus Cokro Kembang Jenawi Karanganyar. Basicedu's Journal, 2 (1), 11-18.

[24]. Khusniyah, NL, \& Hakim, L. (2019). The Effectiveness of Online Learning: An Evidence on English Language Learning. Tatsqif Journal,

[25]. Suci, MP (2020). The effectiveness of onlinebased learning in the insya'di stai ma'arif sarolangun course. El-Jaudah: Journal of Arabic Language and Literature Education, 1 (2), 59-68.

[26]. Margono, S. (2010). Educational research methodology: Jakarta: inventions.

[27]. Ramadhani, AF (2019). Morphological and Morphophonemic Aspects in the Tips Book for Becoming an Inspirational, Creative, and Innovative Teacher by Jamal Ma'mur Asmani and Its Relevance in Learning Indonesian in High School. Majapahit Islamic University Mojokerto.

[28]. Nurlaila, N. (2018). The Urgency of Learning Planning in Increasing Teacher Professionalism.Sustainable: Journal of Education Quality Studies, 1(1), 93-112.

[29]. Badi'ah, Z. (2021). Implikasi Teori Belajar Kognitif J. Piaget dalam Pembelajaran Bahasa Arab dengan Metode Audiolongual. Attractive: Innovative Education Journal, 3(1), 76-90. 